\title{
Repeated determination of convective and radiative heat transfer coefficients using 32 zones thermal manikin
}

\author{
Miloš Fojtlín*, Jan Fišer, Miroslav Jícha \\ From 15th International Conference on Environmental Ergonomics (ICEE XV) \\ Portsmouth, UK. 28 June - 3 July 2015
}

\begin{abstract}
Introduction
Average European citizens spend $80 \%$ to $90 \%$ of their workday time indoors, in buildings or vehicles [1]. Owing to this fact, building design in terms of thermal comfort, air quality, and low energy demands is important. In addition, many independent studies provide evidence of improper thermal environment and the negative influence of this on the human body, e.g. [2], [3]. However, such situations can be tackled, in the future, using modern computational methods. To do so there is a need for anatomically detailed heat transfer coefficients that quantify heat flux from a human body. A lot of research has been done in order to investigate heat transfer coefficients in various body postures, wind speeds and wind directions, e.g. [4], [5], [6], [7]. On the other hand, there has not been any emphasis given to measurement reproducibility. A thermal manikin was involved to determine convective and radiative heat transfer coefficients in a sitting and standing posture repeatedly.
\end{abstract}

\section{Methods}

Presented study involves the state-of-the-art thermal manikin (Newton). The manikin imitates human metabolic heat production, measures combined dry heat flux from its surface and also its surface temperature. To separate convective and radiative heat flux portion a low emissivity coating was applied to the surface of the manikin. Next, the manikin was placed into a calibration box that was built inside a climatic chamber to achieve uniform environment $\left(\mathrm{t}_{\mathrm{amb}}=\mathrm{t}_{\mathrm{rad}}=24{ }^{\circ} \mathrm{C} \pm 0.2{ }^{\circ} \mathrm{C}\right.$,

\footnotetext{
* Correspondence: fojtlin@eu.fme.vutbr.cz Department of Thermodynamics and Environmental Engineering, Energy Institute, Faculty of mechanical engineering, Brno University of Technology,
} Czech Republic

\section{Results}

Results of the research are presented via average values of convective and radiative heat transfer coefficients in a complete overview of 32 zones. Data of sitting and standing positions with $95 \%$ confidence error bars are available. The lowest values of convective heat transfer coefficients $\left(\mathrm{h}_{\mathrm{c}}\right)$ are found on the chest $\left(3.3 \mathrm{~W} \cdot \mathrm{m}^{-2} \cdot \mathrm{K}^{-1}\right)$. The highest $h_{c}$ were indicated on the limbs (feet $6.6 \mathrm{~W}$. $\left.\mathrm{m}^{-2} \cdot \mathrm{K}^{-1}\right)$. Generally, $\mathrm{h}_{\mathrm{c}}$ values of the sitting manikin were slightly higher than those of the standing. Opposite logic applies in the case of radiative heat transfer coefficients $\left(h_{r}\right)$ where the $\left(h_{r}\right)$ maximum is on the back $\left(5.5 \mathrm{~W} \cdot \mathrm{m}^{-2} \cdot \mathrm{K}^{-1}\right)$. Due to the manikin's hair, the lowest $\mathrm{h}_{\mathrm{r}}$ value was determined at the manikin's head $\left(3 \mathrm{~W} \cdot \mathrm{m}^{-2} \cdot \mathrm{K}^{-1}\right)$.

\section{Discussion and conclusion}

The results are compared with results of two independent authors [4], [5], [6]. Normally, differences among the authors in the mean coefficient values vary up to $1 \mathrm{~W} \cdot \mathrm{m}^{-2} \cdot \mathrm{K}^{-1}$ per segment. Extremes are found on the head, feet, seat, and back, where different conditions and geometry apply due to the different manikins involved. The trends of the results are mostly complying. In addition, thanks to the confidence bars we are also able to indicate systematic errors in measurements (lower limbs). To sum up, we have proven reproducibility of the method used, yet in a limited scale. 


\section{Acknowledgements}

The research was supported by the project L01202 NETME CENTRE PLUS with the financial support from the Ministry of Education, Youth and Sports of the Czech Republic under the "National Sustainability Programme I". The authors gratefully acknowledge the support from the project No. FSI-S-142355 of the BUT.

Published: 14 September 2015

\section{References}

1. OFFICE FOR OFFICIAL PUBLICATIONS OF THE EUROPEAN COMMUNITIES: How Europeans spend their time. Luxemburg: European Communities 2004, 132, s.ISBN 92-894-7235-9.

2. Ailu CHEN, victor WC, Chang: Human health and thermal comfort of Office workers in Singapore. 2012, 58:172-178, December.

3. PARSON KC: Human Thermal Environments Taylor \& Francis; 2003.

4. De DEAR, et al: Convective and radiative heat transfer coefficients for individual human body segments. Int I Biometeorol 40, 141-156, ISB '97.

5. Quintela $D$, et al: Analysis of sensible heat exchanges from a thermal manikin. Eur J Appl Physiol 2004, 92:663-668.

6. Oliveira AVM, et al: Journal of Wind Energy Ind. Aerodynamics 2014, 132:66-76.

7. Kurazumi $Y$, et al: Radiative and convective heat transfer coefficients of the human body in natural convection. Elsevier Ltd.: Building and Environment;43(2008):2142-2153.

doi:10.1186/2046-7648-4-S1-A160

Cite this article as: Fojtlín et al:: Repeated determination of convective and radiative heat transfer coefficients using 32 zones thermal manikin. Extreme Physiology \& Medicine 2015 4(Suppl 1):A160.

\section{Submit your next manuscript to BioMed Central and take full advantage of:}

- Convenient online submission

- Thorough peer review

- No space constraints or color figure charges

- Immediate publication on acceptance

- Inclusion in PubMed, CAS, Scopus and Google Scholar

- Research which is freely available for redistribution

Submit your manuscript at www.biomedcentral.com/submit
C Biomed Central 